\title{
Can a Right of First Refusal Be Assigned?
}

\author{
Jonathan F. Mitchell $\dagger$
}

A right of first refusal, also known as a "preemptive right," is a right to purchase in advance of all others on specified terms, but it is only triggered if the owner decides to sell. ${ }^{1}$ Rights of first refusal can exist in real estate, ${ }^{2}$ corporate securities, ${ }^{3}$ franchise agreements, ${ }^{4}$ oil and gas leases, employment contracts, and all sorts of commercial assets.' Most preemptive rights are created by the agreement of the parties; however, both Congress and state legislatures have provided for statutory rights of first refusal, usually to protect franchisees, tenants, or farmers.

Most rights of first refusal allow the rightholder to purchase at the same price offered by a third party. However, parties may sometimes arrange a "fixed price" right of first refusal that permits the rightholder to preempt a third party at a prearranged price, even if the third party offers a higher price. Because of judicial hostility to these

$\dagger$ B.A. 1998, Wheaton College; J.D. Candidate 2001, The University of Chicago.

1 Because the holder of a right of first refusal cannot compel the owner to sell, see Annotation, Pre-Emptive Rights to Realty as Violation of Rule Against Perpetuities or Rule Concerning Restraints on Alienation, 40 ALR3d 920, 924-25 (1971) (describing basic characteristics of preemptive rights), it is distinguishable from an ordinary option and is best described as a contingent option.

2 Board of Education of Worthington City School District v Homewood Corp, 1996 Ohio App LEXIS 3519,*1 (involving right of first refusal of repurchase of undeveloped land).

3 Braun Welding Supply, Inc v Praxair, Inc, 654 S2d 388, 389-90 (La App 1995) (involving right of first refusal in sale of a corporation's stock). See also F. Hodge O'Neal and Robert B. Thompson, O'Neal's Close Corporations $\$ 7.05$ at 18 (Callaghan $3 \mathrm{~d}$ ed 1996) (stating that option agreements are the "most common of transfer restrictions" and these often take the form of a right of first refusal).

4 Schupack v McDonald's System, Inc, 200 Neb 485, 264 NW2d 827, 828 (1978) (involving right of first refusal to operate a fast food franchise).

5 Perritt Co v Mitchell, 663 SW2d 696,697 (Tex App 1983) (involving right of first refusal in oil, gas, and mineral leases).

6 American Broadcasting Companies, Inc v Wolf, 76 AD2d 162, 430 NYS2d 275, 277 (1980) (involving a right of first refusal that gave the employer an opportunity to match any offer from another company "only in substance and not in every particular" for three months after the expiration of the original employment contract).

7 See, for example, West Texas Transmission, LP v Enron Corp, 907 F2d 1554, 1556 (5th Cir 1990) (involving a right of first refusal in a natural gas pipeline).

8 See, for example, Petroleum Marketing Practices Act, Pub L No 103-371, 108 Stat 3484 (1994), codified at 15 USC $\$ 2802$ (1994) (granting a service station franchisee a right of first refusal to purchase the station if the distributor wishes to sell the property). Several states have passed statutes that give farmers whose land has been foreclosed a right of first refusal to repurchase the land when the foreclosing agency attempts to sell it. See Minn Stat Ann $\S 500.245$ subd 1(a) (West 1990 \& Supp 2001); Iowa Code Ann $\S 654.16$ A (West 1995). 
arrangements,' as well as the unpredictable costs that such rights may impose on the contracting parties, ${ }^{10}$ these "fixed price" preemptive rights are rare."

While the law generally favors the assignability of contractual rights, ${ }^{12}$ contracts that are deemed "personal" cannot be assigned or devised. ${ }^{13}$ In the context of preemptive rights, deciding the assignability raises numerous questions of common law property, freedom of contract, and rules of construction for contracts, deeds, and wills. The courts have not yet devised a coherent framework for deciding when a right of first refusal can be assigned, and the varied contexts in which such rights arise greatly complicate the problem.

In some cases, moreover, the issue will be of little practical consequence, especially if the encumbered property is freely alienable after the preemptive right has been exercised. For example, if a right of first refusal is declared "personal" by the courts, what can prevent the rightholder from exercising that right on behalf of a third party, to whom he can later sell the underlying property $?^{14}$ How can legislation (or judicial rules) be crafted to prevent such circumvention without imposing draconian restraints on alienability? ${ }^{15}$ If such rules are impossible to develop in certain situations, does that make all preemptive rights de facto assignable?

Despite these objections, the courts should develop a default rule that rights of first refusal are personal, and not assignable, unless the parties' agreement clearly indicates otherwise. This approach would be preferable to relying on a case-by-case determination of the par-

9 See, for example, Iglehart $v$ Phillips, 383 S2d 610, 615-16 (Fla 1980) (involving a fixed price right of first refusal of indefinite duration that the court held was an unreasonable restraint on alienation); Colen v Patterson, 436 S2d 182, 182 (Fla App 1983) (same); Missouri State Highway Commission v Stone, 311 SW2d 588, 590 (Mo App 1958) (same).

10 For a general discussion, see David I. Walker, Rethinking Rights of First Refusal, 5 Stan J L, Bus \& Fin 1,14-25 (1999). If $A$ grants $B$ a right of first refusal to purchase a plot of land at a fixed price of $\$ X$, regardless of what the third party offers, one of two things may happen: (1) the market price may be less than $\$ X$ at the time the right is triggered, in which case the right would be worthless to the rightholder, $B ;(2)$ the market price may be greater than $\$ X$ at the time $A$ wishes to sell the land encumbered by the preemptive right, making him reluctant to sell.

11 Id at 9.

12 See Scott v Fox Brothers Enterprises, Inc, 667 P2d 773, 774 (Colo App 1983) (finding assignability of a real estate option absent a provision to the contrary).

13 See Sweeney v Lilly, $198 \mathrm{~W}$ Va 202, 479 SE2d 863, 866 (1996) (discussing the majority rule that an option to purchase when devised in a will is personal to the optionee and cannot be exercised by anyone else); Masterson $v$ Sine, $68 \mathrm{Cal} 2 \mathrm{~d} 222,436 \mathrm{P} 2 \mathrm{~d}$ 561, 566 (1968) (applying the personal-assignable contract distinction to real estate); Dahl v Zabriskie, 249 Iowa 584, 88 NW2d 66, 67 (1958) (same).

14 See Rushford State Bank v Kjos, 445 NW2d 846, 849 (Minn App 1989) (holding that a former owner may legally assign his right to property after exercising his statutory right of first refusal).

15 See, for example, Minn Stat Ann $\S 500.24,500.245$ (West 1990 \& Supp 2001) (granting rights of first refusal to former owners of foreclosed farms). 
ties' intent, as it will promote judicial economy and reduce the costs of contracting. In addition, this default rule will often save preemptive rights from invalidation under the Rule Against Perpetuities. Finally, because contracting parties are not indifferent to who is on the other side of the agreement, this rule will protect the autonomy of contracting parties.

Part I explores why parties enter into agreements containing rights of first refusal, which is an important factor in determining whether they should be assignable. It discusses the two main purposes served by preemptive rights (the prevention of bargaining breakdown and the inhibition of exit by the owner of the encumbered property) and whether these purposes sufficiently explain the existence of such rights in many different contexts (such as franchise agreements, real estate, and closely held corporations). Part II summarizes the judicial response to disputes involving the assignability of rights of first refusal, highlighting the complications caused by the Rule Against Perpetuities and the common law ban on unreasonable restraints on alienation. Part III then shows why a default rule against assignability would be desirable in four different contexts: franchise agreements, statutory rights of first refusal, preemptive rights in real property, and close corporations. It concludes by questioning the traditional distinction between "personal" and "assignable" contracts and asserting that a default rule of nonassignability of preemptive rights will actually promote freedom of contract.

\section{WHY PARTIES ENTER INTO RIGHT OF FIRST REFUSAL AGREEMENTS}

Courts have described a right of first refusal as a "valuable right" ${ }^{16}$ and a "powerful instrument." ${ }^{17}$ However, there is little discussion in the case law of why parties enter into such arrangements in the first place. Exploring the purposes of preemptive rights is essential in determining whether, and under what conditions, they should be assignable.

\section{A. Theoretical Explanations for Rights of First Refusal}

1. Preventing bargaining breakdown.

The main rationale behind rights of first refusal is the idea that the rightholder will likely value the encumbered property more highly than any third party bidder, either because of investments made in the 
property, or perhaps because of intangible value from using the property over a long period of time (such as business goodwill, sentimental value, etc.). Usually, however, someone in this position could simply outbid any third party seeking to purchase the property, so at first glance, assuming both parties are rational, a right of first refusal should not be necessary to provide this added security. ${ }^{18}$ However, transaction costs, strategic bargaining, and asymmetric information may prevent the property from being sold to the person who values it the most, so a right of first refusal has been traditionally seen as insurance against a future bargaining breakdown.

\section{Inhibiting exit.}

Recent commentary, however, has questioned this traditional explanation for why parties enter into rights of first refusal. The existence of a preemptive right may deter potential buyers from making offers because it reduces their expected return from the costs they incur in negotiating and making an offer. ${ }^{20}$ This makes the right of first refusal costly for the contracting parties because it reduces the amount that can be obtained from the sale of the property. In addition, the possibility of subsequent purchase from the rightholder (if he exercises his preemptive right against the third party bidder) is not as easy a solution to this problem as some may think. ${ }^{22}$ On the other hand, a potential bidder might be willing to offer more for property encumbered by a (non-fixed price) right of first refusal, to deter the rightholder from exercising his right. ${ }^{23}$ Given the uncertainty

18 David I. Walker, in evaluating these traditional explanations for rights of first refusal, argues that they are "fundamentally about the risk that the higher valuing insider will fail to consummate a purchase, despite his higher valuation," Walker, 5 Stan J L, Bus \& Fin at 29 (cited in note 10) (emphasis added).

19 See id at 29-31 (explaining how bargaining breakdown may occur absent a right of first refusal); Marcel Kahan, An Economic Analysis of Rights of First Refusal 15-18, New York University, Center for Law and Business, Working Paper No 99-009*15-18 (June 1999), available online at <http://papers.ssrn.com/paper.taf?abstract_id=11382> (visited March 26, 2001) (explaining that rights of first refusal may increase efficiency by improving rightholders' incentives to increase the value of the property and by reducing the costs associated with strategic bargaining).

20 See Walker, 5 Stan J L, Bus \& Fin at 23 (cited in note 10).

21 See id at 27 . Walker also relies on anecdotal evidence from practicing attorneys who suggest that rights of first refusal in corporate stock and in real estate deter potential buyers. See id at 25 .

22 See id at 24. If the rightholder exercises his right, Walker argues that the unsuccessful bidder only knows that her bid was less than the value of the property to the rightholder; she does not know whether the rightholder actually values it more highly than she does. Hence, negotiations with the rightholder may be futile and will still add costs to the process. Moreover, in the shareholder context, the other shareholders will often maintain their preemptive rights in the shares purchased by the rightholder.

23 A potential buyer, encountering another potential buyer possessing a right of first refusal at, say, the market price, might consider bidding very high in order to discourage the buyer 
surrounding how much the rightholder values the encumbered property, the third party bidder will not want his efforts to be wasted if the rightholder matches his offer.

David I. Walker claims that a commitment to auction ${ }^{24}$ (where the rightholder is notified of the owner's intent to sell and given the opportunity to participate in an auction) would be a less costly way to prevent future bargaining breakdown between the parties. ${ }^{25}$ Because parties continue to opt for the more expensive right of first refusal, there is likely another motive for such arrangements: to inhibit exit. ${ }^{26}$ Especially in the close corporation context, where stability is valued, Walker argues that the primary purpose of preemptive rights is to prevent the unilateral departure of a partner. ${ }^{27}$ The desire to inhibit exit seems less plausible, however, in franchise agreements or real estate, so it is important to analyze the different contexts in which preemptive rights arise.

\section{B. Common Preemptive Rights}

1. Franchise agreements.

Some commentators have suggested that a right of first refusal creates incentives for rightholders to invest. ${ }^{28}$ For example, a lessee or a franchisee may be reluctant to invest in his property or business if the lessor or franchisor can refuse to renew his agreement at whim. While a longer-term contract would also spur investment by protecting a contracting party from an opportunistic refusal to deal, such an arrangement would also commit the party to a long-term relationship unless he can negotiate a release. With a right of first refusal, however, the rightholder maintains his exit option - he can simply decline to exercise the right. Preemptive rights, therefore, can maintain flexibility

possessing the right of first refusal from even bothering to match. In this way, the high bidder, lacking any right of first refusal, would save resources that might otherwise be spent bargaining with the rightholder.

24 See id at $40-41$ (describing how a commitment to auction would work). The property would be awarded to the highest bidder or retained by the owner if the highest bid fell short of his "reservation price."

25 See id at $40-43$.

26 See id at 43.

27 See id at 44 . Walker points out that unlike naked restraints on sales, rights of first refusal have largely been accepted by the courts and therefore are more effective in restraining alienation than their more drastic counterparts. See id.

28 See Kahan, An Economic Analysis of Rights of First Refusal at *15 (cited in note 19); Walker, 5 Stan J L, Bus \& Fin at 36 (cited in note 10). In American Broadcasting Companies, Inc $v$ Wolf, 76 AD2d 162, 430 NYS2d 275 (1980), the court noted that rights of first refusal are used by employers in the broadcasting industry to retain "the services of major talent in whom the broadcaster has made a significant investment." Id at 280-81. See also Christopher T. Wonnell, The Contractual Disempowerment of Employees, 46 Stan L Rev 87, 108 (1993) (discussing the right of first refusal in American Broadcasting Companies). 
while preventing opportunism and may often be more desirable than a long-term or short-term contract.

\section{Preemptive rights in real property.}

The "inhibiting exit" rationale does not seem as plausible in the context of real estate. It seems most unlikely that one would purchase a right of first refusal in real estate in order to prevent the property owner from selling the property. On the contrary, the rightholder is probably anxious to purchase the property and would like the property owner to dispose of it as soon as possible. Perhaps the failure of parties to take advantage of the commitment to auction reflects the fact that it has not yet been developed as a contractual device, and parties are reluctant to use such an untested and uncertain legal right. ${ }^{29}$ Therefore, it seems that in the context of real property, the traditional explanation that parties are seeking to avoid a bargaining breakdown remains a valid explanation for why parties create rights of first refusal.

\section{Closely held corporations.}

In closely held corporations, commentators have argued that rights of first refusal (like all other restrictions on the alienation of shares) principally serve the purpose of maintaining family control or ensuring compatibility with management. ${ }^{30}$ Such restrictions may also enable compliance with the federal securities laws. ${ }^{31}$ The "inhibition of exit" theory of preemptive rights is strongest in this context.

\section{Statutory rights of first refusal.}

Some midwestern states have granted rights of first refusal to the former owners of foreclosed farms. ${ }^{32}$ Minnesota enacted such a law in 1986 to "encourage and protect the family farm as a basic economic unit, to insure it as the most socially desirable mode of agricultural production, and to enhance and promote the stability and well-being of rural society in Minnesota and the nuclear family." rights of first refusal are not created by the market, but rather im-

29 Walker acknowledges this point, admitting that he is unaware of such a device currently in use. See Walker, 5 Stan J L, Bus \& Fin at 42 (cited in note 10).

30 See Frank H. Easterbrook and Daniel R. Fischel, The Economic Structure of Corporate Law 229 (Harvard 1991) (discussing restrictions on alienation of shares of closely held corporations).

31 See O'Neal and Thompson, O'Neal's Close Corporations at $\$ 7.02$ (cited in note 3 ).

32 See, for example, Iowa Code Ann $\S 654.16$ (West 1995) (allowing a mortgagor to redeem a homestead at fair market value).

33 Minn Stat Ann $\$ 500.24$, subd 1. 
posed by statute, commentators have viewed them with suspicion. ${ }^{34}$ Because preemptive rights discourage bidders and therefore impose costs on both parties to the transaction, ${ }^{35}$ these statutory rights have been criticized for their adverse economic effects. ${ }^{36}$

Regardless of whether such statutory rights of first refusal are socially desirable, the legislatures and the courts must decide whether they can be assigned. In Rushford State Bank $v$ Kjos, ${ }^{37}$ the court held that a former owner of a foreclosed farm may legally assign his right to the property after exercising his statutory right of first refusal. ${ }^{38}$ In response, the Minnesota legislature amended the statute to prohibit assignments, confining the right of first refusal to the former owner and his heirs. ${ }^{39}$ In 1988, the legislature again amended the statute to outlaw prearranged sales between the former owner and a third party, before the former owner exercised his right of first refusal. ${ }^{40}$ If a third party bidder's first offer to the lending institution is matched by the former owner, however, the third party is allowed to make additional offers to the rightholder after the right of first refusal is exercised, provided that there was no collusion between the bidder and the rightholder. ${ }^{41}$

Even if this distinction between transfers arranged before and after the exercise of the preemption right may resolve issues under the statute, the improper use of the right of first refusal may raise other complications. In Schumacher $v$ Ihrke, the court held that even though the statute may allow the sale of property after exercising the right of first refusal, the rightholder may still be liable to a third party bidder for tortious interference of contract. ${ }^{4}$

One commentator has suggested that a statutorily imposed commitment to auction would be preferable to a regime of statutory rights

34 See Thomas J. Houser, Note, A Comparative Study of the Former Owner's Right of First Refusal Upon a Lender's Resale of Foreclosed Agricultural Land: A New Form of State Mortgagor Relief Legislation, 13 J Corp L 895, 907-14 (1988) (reviewing and criticizing the statutes); Robert M. Lawless, Note, The American Response to the Farm Crises: Procedural Debtor Relief, $1988 \mathrm{U}$ Ill L Rev 1037, 1062-63 (same).

35 See text accompanying notes 20-22.

36 See Walker, 5 Stan J L, Bus \& Fin at 55 (cited in note 10) (arguing that "[s]uch a statute transfers value from bank to farmer and depresses the expected value of the farmland in a sale, and this appears to be a case in which the impact of the right of first refusal is significant").

37445 NW2d 846 (Minn App 1989).

38 Id at 849.

39 See Elfering $v$ Schleusner, 1991 Minn App LEXIS 530, *3-4 (describing the amendments made to Minn Stat $\S 500.24$ from 1987-88).

40 See Kjesbo v Ricks, 517 NW2d 585, 589 (Minn 1994) (holding that a prearranged sale of property after person exercises his statutory right of first refusal violates the statute).

41 Id.

42469 NW2d 329 (Minn App 1991).

43 Id at 332-34. 
of first refusal. ${ }^{44}$ Because the existence of preemptive rights discourages bidders, the statutes impose costs on both the lending institution and the farm owner. Moreover, by reducing what the bank can obtain in a foreclosure sale of the property (since fewer people will bid and because the former owner need only match, rather than outbid, offers from competitors), nonwaivable preemptive rights will lead to higher interest rates and more restrictive lending practices. ${ }^{45}$ The distributive consequences of the preemptive right will benefit defaulting farmers, not at the expense of banks, but at the expense of the nondefaulting borrowers. Therefore, courts should hesitate before allowing the assignability of such rights in the name of furthering the statutory purpose of protecting farmers. ${ }^{46}$ In Minnesota, the statute has already decided this issue for the courts.

\section{Current LaW}

\section{A. When Assignability Is Explicitly Addressed in the Contract}

Courts have generally held that the intent of the parties is dispositive in deciding whether a right of first refusal is assignable or personal. ${ }^{47}$ Where a contract explicitly provides that the right be transferable, courts will usually defer to this provision. ${ }^{48}$ However, in Vogel $v$ Melish, ${ }^{49}$ the court held that a preemptive right in a stockholder's agreement was personal, despite an express provision that the agreement "shall be binding upon and inuring to the benefit of the parties hereto and their respective administrators, executors, heirs and personal representatives." signs.") The Vogel court reasoned that as a restraint on alienation, the

\footnotetext{
44 See Walker, 5 Stan J L, Bus \& Fin at 56 (cited in note 10).

45 See id at 55-56.

46 Judge Posner has explained:
}

The idea that favoring one side or the other in a class of contract disputes can redistribute wealth is one of the most persistent illusions of judicial power. It comes from failing to consider the full consequences of legal decisions. Courts deciding contract cases cannot durably shift the balance of advantages to the weaker side of the market; they can only make contracts more costly to that side in the future, because franchisors will demand compensation for bearing onerous terms.

The Original Great American Chocolate Chip Cookie Co, Inc v River Valley Cookies, Ltd, 970 F2d 273, 282 (7th Cir 1992).

47 See, for example, Midwest Communications, Inc v Minnesota Twins, Inc, 779 F2d 444, 455 (8th Cir 1985) (stating that "[w]hen construing a contract, the fact-finder must allow the parties' intent to prevail").

48 See, for example, Jordahl v Concordia College, 1998 Minn App LEXIS 6, *6 (enforcing a written agreement that allowed a right of first refusal to be assigned only with the written consent of the grantor, a college).

4931 IIl 2d 620, 203 NE2d 411 (1964).

so Id at 412-13. 
shareholder's agreement was to be strictly construed..$^{\text {st }}$ It also emphasized the "personal character" of the agreement in holding that the contract "does not negate the implied condition that death of either party excuses the survivor from further performance.",52

At the other extreme, the parties' contract might expressly declare that the right of first refusal is personal, and courts will usually agree. But in Smith $v$ Smith, ${ }^{53}$ the court held a right of first refusal to be assignable, even though the contract explicitly stated that it was personal and could not be assigned. ${ }^{54}$ The court did so because the contract was "replete with references to successors in interest.",ss

Therefore, Vogel and Smith show that simply labeling a right of first refusal as "personal" or "assignable" in the contract will not automatically resolve the issue in court. Both cases contained unusual fact patterns (the contract in Vogel left out "assigns" and the contract in Smith contained provisions that contradicted its "personal" label), however, that tipped the scale away from the explicit language in the contract. Absent such unusual facts, contracting parties that explicitly write their intent into their agreement will usually have their intent upheld in court.

\section{B. Problems with Assignability}

The more challenging cases involve contracts where the parties' intent is unclear as to assignability, and courts have taken widely divergent approaches. Some courts will construe a right of first refusal as personal unless language such as "heirs and assigns" is included in the contract. ${ }^{56}$ Other courts will construe the preemptive right as assignable, even without this precise language."

Though courts may differ on the need for "magic words," absent any evidence of intent, preemptive rights are generally construed as nontransferable. ${ }^{58}$ Still, the strength of the presumption may differ depending on the context.

51 Id at 413.

52 Id at 414.

53 116 AD2d 810, 497 NYS2d 192 (1986).

54 Id at 193.

55 Id. The Smith court went on to hold that this interpretation of the agreement rendered the right of first refusal violative of the Rule Against Perpetuities. See id.

56 See, for example, Davis $v$ Anthony, 1998 Ohio App LEXIS 6177, *6 (holding that a right of first refusal is unassignable, unless language such as "heirs and assigns" is included in the contract).

57 See, for example, Brooks v Terteling, 107 Idaho 262, 688 P2d 1167, 1169-70 (1984) (holding that a grant of a right of first refusal need not contain the language of "heirs and assigns" to be assignable).

58 See Matter of Wauka, Inc, 39 BR 734,737 (N D Ga 1984) (holding that a right of first refusal is personal because it did not include the grantee's "successors or assigns," though it was binding on the grantor's "successors or assigns"); Sweeney v Lilly, $198 \mathrm{~W}$ Va 202, 479 SE2d 863, 


\section{Problems with the Rule Against Perpetuities.}

One important issue for the courts is whether to interpret the assignability of a preemptive right in a way that would invalidate it. Nonpersonal preemptive rights are more likely to conflict with the Rule Against Perpetuities and the common law rules against restraints on alienability. In ascertaining the "intent" of the parties, it would seem odd to interpret an ambiguous contractual provision in a way that would render it void. ${ }^{60}$ At the same time, the parties may not be conscious of these common law rules when negotiating and drafting their agreement.

In traditional common law jurisdictions, a right of first refusal of indefinite duration violates the common law Rule Against Perpetuities. ${ }^{61}$ Because a freely assignable preemptive right might conceivably vest outside the common law time limit, ${ }^{62}$ numerous courts have declared these assignable rights to be void. ${ }^{63}$

This does not mean, however, that all rights of first refusal must be personal or else invalid in these jurisdictions. Individual parties

866 (1996) (holding that an option to purchase in a will is presumed to be personal and not assignable); Davis, 1998 Ohio App LEXIS 6177 at *6 (holding that a right of first refusal is unassignable, unless language such as "heirs and assigns" is included in the contract); Board of Education v Homewood Corp, 1996 Ohio App LEXIS 3519, *7 (holding that a right of first refusal in land is personal and cannot be assigned); Morris $v$ Walls, 1996 Del Ch LEXIS 158, *7-9 (holding that a right of first refusal in land is not assignable because assignability was not explicit in the contract); Bloomer $v$ Phillips, 164 AD2d 52, 562 NYS2d 840, 842 (1990) (holding that a right of first refusal that was not made binding on the plaintiffs' heirs and assigns would terminate upon plaintiffs' deaths); Old National Bank of Washington v Arneson, 54 Wash App 717, 776 P2d 145, 148-49 (1989) (discussing the presumption of nontransferability).

59 Because a personal right of first refusal will expire at the death of the rightholder, it will always vest within twenty-one years of lives in being. Also, its limited time will more likely be seen as a reasonable restraint on alienation, rather than a preemptive right that will encumber the property ad infinitum. See Fisher $v$ Fisher, 23 Mass App 205, 500 NE2d 821, 822 (1986) (noting that restraints upon alienation are disfavored, so if one construction imposes less of a restraint than another, the less restraining construction is preferred).

60 In the choice-of-law context, see Restatement (Second) of Conflicts of Laws $\$ 187 \mathrm{cmt}$ e at 565-66 (1969) (stating that if the chosen law in the parties' choice-of-law clause invalidates the contract, it should be disregarded as a mistake). But see Foreman v George Foreman Associates, 517 F2d 354, 357 (9th Cir 1975) (choosing law that invalidates a contract where public policy favors invalidation).

61 The common law Rule Against Perpetuities says that any interest, to be valid, must vest or fail within lives in being plus twenty-one years. Black's Law Dictionary 1331 (West 7th ed 1999). See also note 59.

62 If $X$ conveys to $Y$ a right of first refusal in land that $X$ owns, and that right is freely assignable, then $Y$ could sell the right to $Z$. Because $Z$ could exercise this right more than twentyone years after $X$ and $Y$ (the only lives in being) are dead, the right of first refusal would violate the Rule Against Perpetuities.

63 See, for example, Nash v Scott, 62 Ark App 8, 966 SW2d 936, 937 (1998) (holding that a right of first refusal in land granted to an individual and his "heirs and assigns" violates the Rule Against Perpetuities); Buck v Banks, 668 NE2d 1259, 1261 (Ind App 1996) (holding that a right of first refusal, applied to "all heirs, executors, administrators and assigns" violates the Rule Against Perpetuities). 
could create assignable rights that expire twenty-one years after their death, and corporate parties could create assignable rights that expire twenty-one years after the right's creation. ${ }^{64}$ The purchaser of the rights would likely be on notice of when the rights expire, so their limited duration should not have a chilling effect on their transferability, although it might affect their price.

Unfortunately, the contracting parties in these jurisdictions often neglect explicitly to limit the duration of a right of first refusal. While some courts will invalidate these rights, others will interpret these rights (in commercial contexts) to last only for twenty-one years so as not to violate the Rule. ${ }^{65}$ Other courts rewrite the contract to make the right expire within a "reasonable time." ${ }^{, 66}$ Moreover, some courts will interpret a right of first refusal as personal even though the contract is silent as to its assignability, because constructions that avoid violating the Rule Against Perpetuities are favored. ${ }^{6}$

In jurisdictions that have adopted the "wait and see" doctrine, ${ }^{68}$ a freely assignable right of first refusal will be valid if exercised within twenty-one years after the most recent death. ${ }^{69}$ However, "wait and see" may not be retroactively applied to save rights created before its adoption."

In some jurisdictions that have retained the Rule Against Perpetuities, a right of first refusal is not even subject to the Rule. ${ }^{71}$ Hence,

64 See Ferrero Construction Co v Dennis Rourke Corp, 311 Md 560, 536 A2d 1137, 1144 (1988) (holding that a right of first refusal between two corporations, not limited to a term of years, violates the Rule Against Perpetuities).

65 See Continental Cablevision of New England, Inc v United Broadcasting Co, 873 F2d 717, 729-30 (4th Cir 1989) (discussing the Rule Against Perpetuities as applied to commercial transactions).

66 See Mazzeo v Kartman, 234 NJ Super 223, 560 A2d 733, 737 (1989) (holding that a right of first refusal that lasts "forever" violates the Rule Against Perpetuities but that if a judge cannot determine the actual intent of the parties, he should determine a "reasonable time" for the expiration of the right).

67 See Nickels v Cohn, 764 SW2d 124, 132-33 (Mo App 1989) (holding that a right of first refusal that does not contain the words "heirs and assigns" is personal and does not violate the Rule).

68 The "wait and see" doctrine looks to actual events as they unfold, rather than possibilities. See Black's Law Dictionary at 1574 (cited in note 61). Rather than voiding the preemptive right because of the possibility that it might vest more than twenty-one years after lives in being, the "wait and see" approach saves the right if it actually is exercised during that time.

69 See McCormick v Camp Pocono Ridge, Inc, 781 F Supp 328, 335 (M D Pa 1991) (holding that the Rule was not violated when the relevant persons (lives in being) had only been dead for thirteen years because it had been exercised within twenty-one years of the death of the grantor); JVI Builders, Inc v First Citizens Corp, 1995 Va Cir LEXIS 1401, *17-18 (holding that a right of first refusal in land owned by a corporation would ordinarily violate the Rule, but the "wait and see" statute allows it to be exercised within twenty-one years of the creation of the interest).

70 See Lake of the Woods Association, Inc v McHugh, 238 Va 1, 380 SE2d 872, 875 (1989) (discussing retroactive application of "wait and see" statutes).

71 See Gartley $v$ Ricketts, 107 NM 451, 760 P2d 143, 145 (1988) (holding that a right of first refusal is not a future interest and not subject to the Rule); Robroy Land Co, Inc v Prather, 95 
assignable rights of indefinite duration held by persons or corporations will be valid in these jurisdictions.

Other courts have relied on policy considerations in exempting rights of first refusal from the Rule Against Perpetuities. One court, while acknowledging that an assignable right of first refusal in a condominium association would be a "technical" violation of the Rule, nevertheless invoked "important considerations of public policy" and upheld the right." Another court allowed an explicitly transferable right of indefinite duration because it would be "compatible with the policies of commerce and utilization of land." ${ }^{73}$

New York has recognized a narrower exception to the Rule Against Perpetuities for rights of first refusal, applying it to commercial and governmental transactions, but not to transactions between private individuals. ${ }^{74}$ Hence, courts in New York are more likely to interpret rights of first refusal between private individuals as personal rather than assignable, in order to save them from the Rule Against Perpetuities. $^{75}$

The Restatement (Third) of Servitudes has completely exempted rights of first refusal from the Rule Against Perpetuities, rejecting the position of the Restatement (Second) of Property. ${ }^{76}$ The Restatement (Third) notes that a growing number of courts have rejected application of the Rule Against Perpetuities, recognizing that it needlessly invalidated legitimate transactions."

\section{Unreasonable restraints on alienation.}

Preemptive rights may also be void as unreasonable restraints on alienation. Factors to consider in deciding whether such a restraint is reasonable include (1) its purpose; (2) its duration; and (3) the method

\footnotetext{
Wash 2d 66, 622 P2d 367, 370 (1980) (holding that a right of first refusal is a personal right rather than an interest in land and, therefore, is not subject to the Rule).

72 See Cambridge Co v East Slope Investment Corp, 700 P2d 537, 540 (Colo 1985) (stating that "[c]ourts have not applied the [R]ule mechanically where its purposes [preventing restraint on alienation and encouraging improvement of property] will not be served").

73 Shiver v Benton, 251 Ga 284, 304 SE2d 903, 907 (1983) (holding that a right of first refusal by tenants in common does not violate the Rule).

74 Compare Metropolitan Transportation Authority v Bruken Realty Corp, 501 NYS2d 306, 492 NE2d 379, 384 (1986) (stating that "neither 'lives in being' nor 'twenty one years' are periods which are relevant to business or governmental affairs"), with Adler $v$ Simpson, 203 AD2d 691, 610 NYS2d 351, 353-54 (1994) (holding that a right of first refusal in land is personal and cannot be assigned). The distinction seems to be that there is less "government or public interest" in private individual transactions as well as the fact that private individuals can be measured by relevant lives in being. See Adler, 610 NYS2d at 354.

75 See Adler, 610 NYS2d at 353-54.

76 Compare Restatement (Third) of Property: Servitudes $\$ 3.3 \mathrm{cmt}$ a at 425 (1991), with Restatement (Second) of Property $\$ 4.4 \mathrm{cmt} \mathrm{c}$ at 211 (1981).

77 Restatement (Third) of Property: Servitudes $\$ 3.3 \mathrm{cmt} b$ at $427-28$.
} 
of determining the price. ${ }^{78}$ As noted earlier, there has been considerable judicial hostility to "fixed price" rights of first refusal (as compared to a right to match the price offered by a third party) because fixed price rights "clearly discourage[ ] any improvements of the land by the existing property owner." An owner of property encumbered by such a right would have little incentive to improve its value beyond the fixed price.

Some courts, however, will uphold fixed price rights of first refusal if they can be interpreted as personal to the original grantee because such rights are not of unlimited duration. ${ }^{80}$ Moreover, one court has suggested that even an assignable fixed price right of first refusal might be upheld. ${ }^{81}$

\section{Covenants running with the land.}

Finally, in the real estate context, some rights of first refusal are construed as covenants running with the land. ${ }^{82}$ Such rights would be assignable, but only as attached to the parcel of land. Most courts, however, seem to hold that a right of first refusal does not touch and concern the land, and therefore is not a real covenant. ${ }^{83}$ These cases,

78 See Hartnett $v$ Jones, 629 P2d 1357, 1363 (Wyo 1981) (holding that a preemptive right is not an unreasonable restraint on alienation where the purpose is limited and the seller sets the price).

79 Iglehart $v$ Phillips, 383 S2d 610,615 (Fla 1980) (holding that a fixed price right of first refusal of indefinite duration was an unreasonable restraint on alienation). See also Restatement (First) of Property $\S 413(2)$ (1944) (stating that a right of first refusal at a fixed price, or at a percentage of the price offered by another person, is valid only if the restraint is valid under Sections 406-11).

80 See Fisher v Fisher, 23 Mass App 205, 500 NE2d 821, 822 (1986) (holding that a right of first refusal in land at a fixed price did not survive the death of the two grantees because the deed did not mention "heirs and assigns" and to hold otherwise would be an unreasonable restraint on alienation).

81 See Rowlee $v$ Dietrich, 88 AD2d 751, 451 NYS2d 467, 469 (1982) (holding that a fixed price preemptive right, explicitly assignable, was not per se an unreasonable restraint on alienation without "additional factors which bear on the reasonableness of the restriction").

82 See In re Coordinated Financial Planning Corp, 65 BR 711,712 (BAP 9th Cir 1986) (noting that, under California law, a right of first refusal is a covenant running with the land); Sherwood Ford, Inc v Ford Motor Co, 860 F Supp 659, 662 (E D Mo 1994) (same, but under Missouri law).

83 See In re Fleishman, 138 BR 641, 644 (Bankr D Mass 1992) (holding that a right of first refusal "does not touch and concern the land" and therefore does not run with the land); Levy $v$ Blue Ridge Construction Co, Inc, 74 Misc 2d 676, 345 NYS2d 314, 316-17 (Sup Ct 1973) (holding that a right of first refusal to purchase land was a personal covenant running only to grantees and not running with the land); Ricketson v Bankers First Savings Bank, FSB, 233 Ga App 11, 503 SE2d 297, 298-99 (1998) (construing a right of first refusal as a personal covenant that did not run with the land); Nichols v Lake Toxaway Co, Inc, 98 NC App 313, 390 SE2d 770, 773-74 (1990) (holding that a right of first refusal, which the deed said "shall run with the land and be binding on all parties and all persons claiming under them in perpetuity," was nevertheless a personal grant because the right was specifically limited to the grantee and not his heirs and assigns); Feider v Feider, 40 Wash App 589, 699 P2d 801, 803-04 (1985) (holding that a right of first 
however, do not address whether the rights of first refusal that fail the real covenant test are assignable apart from land.

\section{Should A Right of First Refusal Be AssignABLE?}

\section{A. Adopting a Presumption Against Assignability}

The courts' current approach to the assignability of preemptive rights, which relies heavily on the intent of the parties, is unsatisfactory. Judicial inquiry into the parties' states of mind is time consuming and expensive, and it becomes almost impossible for such a dispute to be resolved on summary judgment. ${ }^{84}$ Instead, the courts should develop a set of default rules ${ }^{85}$ for these situations, keeping in mind the reasons why the parties entered these arrangements.

The types of default rules a court should consider in these cases include "problem-solving defaults," "equilibrium-inducing defaults," and "information-forcing defaults." A problem-solving default supplies the provision the parties would have chosen "had they been informed, rational, and faced with zero transaction costs." rium-inducing default provides the welfare maximizing term. ${ }^{87}$ Finally, an information-forcing default is usually unfavorable to the more sophisticated party, encouraging him to make clear the terms of the contract to the unsophisticated party.

Contracting parties are not indifferent to who is on the other side of the agreement. The value of a contract will often depend on what type of person possesses the right of first refusal. If a landowner conveys a right of first refusal in a parcel of land next to his house, it will matter greatly to him whether his potential neighbors are orderly or disruptive. While there may be judicial remedies against bad

refusal was not a covenant running with the land, despite the parties' intent that it was, because it did not touch and concern the land and there was no horizontal privity).

84 See Charles Alan Wright, Arthur R. Miller, and Mary Kay Kane, 10B Federal Practice and Procedure $\$ 2732.2$ at 152-53 (West 3d ed 1998) (noting that cases involving "a determination regarding intentions or motives are particularly unsuitable for summary adjudication").

85 There have been at least six categories of default rules recognized by commentators. See Alan Schwartz, The Default Rule Paradigm and the Limits of Contract Law, 3 S Cal Interdiscipl L J 389, 390-91 (1993) (identifying and describing the six categories: problem-solving defaults, equilibrium-inducing defaults, information-forcing defaults, normative defaults, transformative defaults, and structural defaults).

86 Id at 390. See Alan Schwartz and Robert E. Scott, Commercial Transactions: Principles and Policies 1-16 (Foundation 1982) (discussing the Uniform Commercial Code as providing problem-solving default rules).

87 For a general discussion, see Ian Ayres and Robert Gertner, Strategic Contractual Inefficiency and the Optimal Choice of Legal Rules, 101 Yale L J 729 (1992) (examining how transactions costs and market power affect incentives to contract around default rules).

88 See Robert E. Scott, A Relational Theory of Default Rules for Commercial Contracts, 19 J Legal Stud 597, 609-11 (1990) (discussing information-forcing default rules). 
neighbors, ${ }^{89}$ such as nuisance actions, they will often come with substantial litigation costs. A nonassignable right of first refusal would protect the grantor from being forced to sell his property to someone to whom he would rather not sell it.

This problem is not unique to contracts involving preemptive rights; it is pervasive throughout contract law. The law's distinction between "personal" and "assignable" contractual rights ignores the fact that in many "nonpersonal" arrangements, the contracting parties care deeply about who is on the other side of the agreement. In the event of dispute or breach, the contract itself provides limited protection. Expectation damages are often undercompensatory due to litigation costs, ${ }^{91}$ courts are often reluctant to enforce liquidated damages clauses, and parties may be reluctant to sue and expose themselves to the weapons of discovery.

Under the circumstances described above, the courts should treat preemptive rights as personal, and not assignable, unless the parties overcome this presumption with explicit contractual provisions. This default rule will promote greater certainty in outcome, even though there will still be some disputes at the margins over whether the parties' expressed intentions are sufficient to overcome the presumption. Although a default rule against assignability may seem like a restraint on freedom of contract, it will in fact protect the autonomy of contracting parties by preventing them from being stuck in undesirable relationships if the preemptive right can be assigned without their consent. The benefits of this rule can clearly be seen in the varied contexts in which contracting parties seek to create rights of first refusal.

89 See, for example, Griffin v Northridge, 153 P2d 800, 803 (Cal App 1944) (imposing nuisance damages on a neighbor who "wilfully frustrate[d] the peace and comfort of another without just cause").

90 Forbidding the assignment of rights of first refusal would not necessarily solve this problem, especially if the rightholder can exercise his "unassignable" right and then immediately sell the property to the bad neighbors, assuming there are no restraints on alienation on the underlying land. To prevent this, a landowner could make the exercise of the right contingent on the rightholder accepting some limited restraints on alienability, such as preventing him from selling or leasing the land for five years after exercising the right or forbidding him from selling the land for a limited period of time without the consent of the right grantor. The landowner would face a challenge similar to the state of Minnesota's efforts to prevent statutory rights of first refusals from being used by those other than the intended beneficiaries. See Part I.B.4.

91 See Alan Schwartz, The Case for Specific Performance, 89 Yale L J 271, 276 (1979) (arguing that expectation damages may often undercompensate).

92 See, for example, Lake River Corp v Carborundum Co, 769 F2d 1284, 1288-92 (7th Cir 1985 ) (holding a liquidated damages provision in a contract to be an invalid penalty clause).

93 For a general discussion, see Omri Ben-Shahar and Lisa Bernstein, The Secrecy Interest in Contract Law, 109 Yale L J 1885 (2000) (examining the secrecy costs of obtaining compensation for a contract breach). 


\section{B. Application of the Presumption in Different Contexts}

1. Franchise agreements.

There are probably few relationships in contract law where the identity of the party with which one deals is more important than in a franchise arrangement. A poorly managed franchise can stain the reputation of an entire national chain, ${ }^{34}$ and state legislation has made it increasingly difficult for franchisors to terminate underperforming franchisees. It is not surprising that Ray Kroc, the founder of McDonald's, considered the selection of his franchisees to be crucial to his company's success, ${ }^{\circ}$ and that his franchise agreements would expressly prohibit transfer without the consent of McDonald's."

In Schupack v McDonald's System, Inc, ${ }^{98}$ McDonald's had given Bernard Copeland, one of its franchisees in Bellevue, Nebraska, a right of first refusal to purchase any future McDonald's franchises that might be developed in the Omaha, Nebraska and Council Bluffs, Iowa areas. The right, however, did not contain any language regarding its assignability. Copeland later attempted to assign that right, along with all his interests in McDonald's franchises in the Omaha and Council Bluffs areas, to the plaintiff. McDonald's argued that the right of first refusal was intended to be personal to Copeland, and could not be assigned to the plaintiffs. ${ }^{100}$

The trial court ruled against McDonald's and held the right was not a personal contract and was freely transferable. ${ }^{101}$ The Nebraska Supreme Court reversed, claiming that the district court erred in determining the intent of the parties. After giving a detailed history of McDonald's franchise practices and relying heavily on parol evidence, $^{102}$ the court concluded that the right of first refusal was intended to be personal in nature. ${ }^{103}$ The dissent criticized the majority for not

94 See, for example, Denny's Manager Accused of Racial Bias, LA Times A16 (Jan 8, 1998) (discussing alleged racial discrimination at a Denny's franchise).

95 See, for example, Franchise Practices Act, NJ Stat Ann §§ 56:10-1 et seq (West 1989 \& Supp 2000) (requiring franchisors to give written notice at least sixty days in advance detailing all reasons for termination, and forbidding franchisors to "terminate, cancel, or fail to renew a franchise without good cause"). These laws are quite common. See, for example, Ala Stat Ann \$ 8-20-5 (1975) (imposing similar restrictions).

96 See Schupack v McDonald's System, Inc, 200 Neb 485, 264 NW2d 827, 830 (1978) (providing Kroc's testimony on the importance of franchisee selection).

97 Id at 831.

$98200 \mathrm{Neb} 485,264$ NW2d 827, 829 (1978).

99 Id at 835 .

100 Id at 834 .

101 Id at 828 .

102 Id at 829-34.

103 Id at 836 . 
giving proper deference to the trial court's assessment of the evidence.

Given the difficulties in determining the parties' states of mind, and the poor incentives to create explicit provisions caused by the liberal use of parol evidence, the court should have resolved the case by establishing a clear default rule to guide future parties in franchise agreements. The purpose of preemptive rights in the franchise setting is more likely to be insurance against bargaining breakdown for the franchisee than the "inhibiting exit" theory described by Walker.

One option for the court would have been to establish a default rule of assignability. If nonassignability is valuable to the grantor of the preemptive right, perhaps the burden should be placed on the grantor explicitly to contract for this protection, especially if he drafted the contract. Moreover, McDonald's and most other franchisors will be sophisticated parties, which further strengthens the case for a default rule of assignability. This approach could be seen as an information-forcing default rule, ${ }^{106}$ as it encourages the more sophisticated party, the franchisor, to speak up or be penalized.

Nevertheless, a better default rule would have been to declare any right of first refusal in a franchise agreement to be personal, unless the contract explicitly allowed it to be assigned. While it may seem questionable for the law to presumptively block a voluntary, mutually beneficial exchange between the rightholder and the third party, in this case, the transaction will certainly affect the franchisor, who is not privy to their subsequent agreement. The franchisor will have a strong interest in remaining in a continuous relationship with those who exercise a right of first refusal over his franchises. Allowing the franchisee to assign the preemptive right without the franchisor's consent will deprive the franchisor of its much-needed ability to choose franchisees. It is difficult to believe any franchisor would have contracted for the free assignability of rights of first refusal on its franchises, especially with the legal difficulties involved in terminating a franchisee. Thus, a default rule of nonassignability in the franchise context can best be seen as a problem-solving default, ${ }^{107}$ and perhaps an equilibrium-inducing default as well, because the detriment to the

104 Id at 839 (White dissenting).

105 See Part I.A.2.

106 For a general discussion, see Scott, $19 \mathrm{~J}$ Legal Stud at 597 (cited in note 88) (examining the approach courts should take to setting default rules); Ian Ayres and Robert Gertner, Filling Gaps in Incomplete Contracts: An Economic Theory of Default Rules, 99 Yale L J 87 (1989) (same).

107 For a general discussion, see Schwartz and Scott, Commercial Transactions at 1-15 (cited in note 86 ). 
franchisor will outweigh the gains to franchisees resulting from the transfer of the right.

Although either rule would allow the courts to resolve franchise disputes quickly, without the need to evaluate the credibility of witnesses, ${ }^{108}$ a default rule of nonassignability is preferable in this context, where the personal identity of the franchisee is of utmost importance to the franchisor.

2. Preemptive rights in real property.

A default rule that declares all rights of first refusal in real property to be personal and not assignable, unless the contract explicitly says otherwise, would not only resolve cases quickly and marginally protect the autonomy of the grantor of the right, but would avoid some of the complications that arise with assignable preemptive rights.

To begin with, courts have struggled with interpreting contracts that create preemptive rights in the context of the Rule Against Perpetuities. As discussed earlier, a freely alienable right of first refusal may be exercised after twenty-one years plus lives in being. ${ }^{109}$ How should courts respond to contracts that fail to specify the assignability of the right? Should the contracts be altered to fit the Rule? Is it appropriate for courts to "fix" preemptive rights that, due to attorney sloppiness, violate the unforgiving common law Rule ${ }^{110}$ Or, should the Rule be altered to fit the contracts? If so, should these exceptions to the Rule be created by courts on a case-by-case basis, "11 or should the legislature enact a clear, broad exemption for rights of first refusal, as suggested by the Restatement (Third) of Servitudes $\S 3.3 ?^{112}$

A default rule of nonassignability in most cases avoids these difficult questions posed by a case-by-case determination of intent. Courts will still, however, have to confront these Rule Against Perpetuities questions when the contract overcomes the presumption by referring to "assigns." Such a rule will make judging easier and trials less expensive. ${ }^{113}$ Moreover, parties will seldom want an assignable right that would violate the Rule Against Perpetuities, so an inquiry into the

108 See Schupack, 264 NW2d at 835 (doubting the credibility of one of plaintiff's witnesses).

109 See Section II.B.1.

110 See Mazzeo v Kartman, 234 NJ Super 223, 560 A2d 733, 737 (1989) (holding that the trial judge "should determine a 'reasonable time' for the expiration of the right").

111 See Cambridge Co v East Slope Investment Corp, 700 P2d 537, 540-41 (Colo 1985) (holding that courts should not automatically apply the Rule, but should consider public policy).

112 See also 1977 Fla Laws ch 77-23, codified at Fla Stat 689.22(3)(a)(7) (exempting rights of first refusals from the Rule Against Perpetuities, but repealed in 1988), repealed by 1988 Fla Laws ch 88-40, 82 .

113 See note 84 and accompanying text. 
"personal" or "assignable" nature of the right, rather than a problemsolving default rule, seems especially inapt in this context.

Ironically, because of the Rule Against Perpetuities, this default rule of nonassignability, rather than a case-by-case analysis of intent, is more likely to do justice in the particular case and would appear to be the best problem-solving default and equilibrium-inducing default. Under this regime, we get the benefits of rules (such as low decision costs and fair notice) plus most of the benefits typically associated with case-by-case discretion (lower error costs in determining parties' intent). Moreover, there may be cases where the identity of the rightholder is important to the owner of the encumbered property, so this default rule would be preferable to simply abolishing the Rule Against Perpetuities as applied to rights of first refusal.

Finally, someone seeking to purchase the nonassignable right of first refusal can wait until the landowner decides to sell, pay the rightholder to exercise the right, and then resell the land to him, assuming the underlying property is freely alienable. Hence, such a default rule should not completely inhibit land from finding its way to the highest-value user, although it might increase transaction costs. At the same time, however, if the rightholder can effectively exercise the right on behalf of someone else, it appears that the default rule of nonassignability is meaningless and fails to protect the autonomy of the right grantor. The right grantor would need to limit the alienation of the underlying property if the right is exercised and would have to do so expressly in the agreement. This seems to defeat the purpose of such a default rule.

Nevertheless, this default rule of nonassignability is still advantageous in the real estate context as it will save many preemptive rights from the Rule Against Perpetuities as well as promote greater certainty in litigation.

\section{Close corporations.}

Because corporations are not lives in being, interpreting their rights of first refusal as nonassignable will not affect their validity under the Rule Against Perpetuities. ${ }^{114}$ A corporate-owned right of first refusal must vest twenty-one years after its creation if a jurisdiction adheres to the traditional common law Rule Against Perpetuities. ${ }^{115}$ This is unlike a right of first refusal owned by a person, which, if con-

114 See Metropolitan Transportation Authority v Bruken Realty Corp, NYS2d 306, 492 NE2d 379,384 (1986) (discussing the application of the Rule to corporations).

115 See Symphony Space, Inc v Pergola Properties, Inc, 646 NYS2d 641, 669 NE2d 799, 806 (1996) (stating that "[w]here ... the parties to a transaction are corporations and no measuring lives are stated in the instruments, the perpetuities period is simply 21 years"). 
strued as nonassignable, is guaranteed to be exercised during the rightholder's life in being or not at all. Hence, there is less reason for a default rule of nonassignability in this context.

However, when preemptive rights are held by individual stockholders in close corporations, the restrictions usually seek to maintain family control, ${ }^{116}$ ensure compatible management, ${ }^{117}$ or assist in complying with the federal securities laws. ${ }^{118}$ These are goals that will continue throughout the life of the corporation, regardless of who owns the stock.

The courts, however, have not always been sensitive to these functions of preemptive rights in the corporate shareholder setting, and the case law contains little discussion of these issues. In Storer $v$ Ripley, ${ }^{119}$ for example, the court held that a right of first refusal in a shareholder's agreement was personal and not devisable, absent any provision as to what was to occur in event of the death of either party. ${ }^{120}$ If new shareholders purchase the stock, and the other shareholders decline to exercise their rights of first refusal, it would further the purposes of the preemptive rights to allow the newcomer to succeed to the previous owner's right of first refusal. While new shareholders can always purchase new rights of first refusal from the others, this could be a difficult and cumbersome process. Even in a close corporation context with few shareholders, the newcomers would have to get each other shareholder to sell a right of first refusal in his stock, creating incentives for holdouts and bilateral monopolies that will raise transaction costs.

On the other hand, it would be unlikely that the shareholders would want to allow the preemptive right to be assigned to an outsider wholly apart from a transfer of stock. For example, if $X$ assigned his right of first refusal to $Y$ in exchange for money, but $X$ kept his stock, then $Y$, an outsider, would be able to purchase stock the next time any shareholder decided to sell. The other shareholders would have no opportunity to block either the transfer of the preemptive right to $Y$ (because they had no right of first refusal in $X$ 's right of first refusal) ${ }^{121}$ or $Y$ 's subsequent exercise of that right. Allowing such a 30).

116 See Easterbrook and Fischel, Economic Structure of Corporate Law at 229 (cited in note

117 See id.

118 See O'Neal and Thompson, O'Neal's Close Corporations $\$ 7.05$ at 20 (cited in note 3).

11912 Misc 2d 662, 178 NYS2d 7 (Sup Ct 1958).

120 Id at 10. See Vogel $v$ Melish, 31 Ill 2d 620, 203 NE2d 411, 412-14 (1964) (finding preemptive right in a stockholder agreement personal where agreement did not include the word "assigns"). See also notes $49-52$ and accompanying text.

121 Creating a right of first refusal in the other stockholders' rights of first refusal would pose a problem of infinite regress because the second degree right of first refusal could still be assigned. It would, however, diminish the chance of an outsider acquiring stock without the ac- 
transaction would defeat the purposes of restrictive shareholder agreements because an outsider, by offering enough money, could infiltrate a close corporation without giving the insiders a chance to block him.

In the close corporation context, the default rule should again be that the preemptive rights are personal but with an exception if the transfer accompanies a sale of stock. Such a rule would be consistent with the purposes of rights of first refusal in the close corporation context, making this an appropriate "problem-solving" and "equilibriuminducing" default. The sale would take place either because: (1) the other shareholders declined to exercise their rights of first refusal, so they presumably would not object to the new shareholder possessing a similar right, or (2) the other shareholders exercised their rights of first refusal, in which case they would already have a right of first refusal over the other shares.

\section{Burdens of Proof}

The courts have not extensively addressed the burdens of production and persuasion in disputes over the assignability of preemptive rights. One court has held that the party asserting that a preemptive right is invalid bears the burden of proof as to the intent of the parties. ${ }^{12}$ Usually the party seeking to invalidate a right of first refusal will argue that it is assignable, ${ }^{123}$ while the party seeking to preserve it will claim that it is personal. Under a default rules approach, however, the burden of proof will typically fall on the party seeking to establish an interpretation contrary to the default. Hence, rather than assigning the burden of proof to the party arguing for invalidity of the right (which may be unclear given the complicated issues involving the Rule Against Perpetuities), the burden would be placed on the party arguing for assignability.

\section{CONCLUSION}

In enacting default rules for the assignability of preemptive rights, the courts should be sensitive to the reasons such rights are created. Often, the choice of rule will seem to be of little practical consequence, especially when the encumbered property is freely assignable after the exercise of the right. In such cases, the rightholder can prear-

quiescence of the current shareholders.

122 See McInerney $v$ Slights, 1988 Del Ch LEXIS $47, * 12$ (holding that the party challenging validity bears the burden and must prove the "preliminary necessary assertion" that the preemptive right was intended to survive the grantee).

123 This is true because it would be more likely to violate the Rule Against Perpetuities or be void as an unreasonable restraint on alienation. 
range a sale to any third party after exercising his right. There is an exception where such arrangements are prohibited by law, such as with statutory rights of first refusal created by the government, ${ }^{124}$ or when the right grantor has restricted the assignability of the underlying property, as McDonald's did in the Schupack case. ${ }^{125}$ Even in the unexceptional cases, however, a default rule of nonassignability will still serve the purposes of judicial economy and protect rights of first refusal from the Rule Against Perpetuities or the ban on unreasonable restraints on alienation.

In other contexts, particularly close corporations, the shares will still be encumbered by other shareholders' rights of first refusal, even after the transfer of stock. Given the reasons for restrictive shareholder agreements, courts should be reluctant to allow these rights to be separately alienable from the stock unless the agreement explicitly allows it.

A default rule of nonassignability of preemptive rights is preferable to the current regime, where courts attempt to classify the rights as "personal" or "assignable" based on the intentions of the parties. It will preserve judicial resources and make contracting less expensive for the parties by providing a clear rule in advance. Moreover, when the Rule Against Perpetuities is involved, such a default rule will more likely further the parties' intentions by preventing the invalidation of the right. Finally, this default rule should be seen as promoting, rather than inhibiting, the values of autonomy and freedom of contract, as it protects the right grantor from being forced into a contractual relationship with an undesirable party. 